\title{
Internationalization Preparation of Small Medium Enterprises (SMEs) in Medan
}

\author{
Yasmin Chairunisa Muchtar \\ Management Department, Faculty of Economics and Business \\ Universitas Sumatera Utara, Indonesia \\ E-mail: yasminmuchtar@usu.ac.id \\ Inneke Qamariah \\ Management Department, Faculty of Economics and Business \\ Universitas Sumatera Utara, Indonesia \\ E-mail: inneke.qamariah@usu.ac.id
}

Received: Feb. 26, 2017

Accepted: August 7, 2017

Published: October 1, 2017

doi:10.5296/jmr.v9i4.10833

URL: https://doi.org/10.5296/jmr.v9i4.10833

\begin{abstract}
The aim of this research is to analyze the key success factors in promoting the internationalization preparation of Small Medium Enterprises (SMEs) and the restraining factors for SME in internationalization preparation of SMEs. This study uses qualitative research method. Primary Data for qualitative is collected through depth interview on important actors as informants, consist of the five representatives as the adaption of Penta-Helix Model. Supporting factors for internationalization preparation are product uniqueness and high international demand of product. While, the barrier factors are insufficient business network and high competition from other countries. The most suitable recommendation for business owner of SMEs is by optimizing the innovation through local values to produce unique product which can compete with other countries. Moreover, the other recommendation is by establishing a wider and stronger business network in order to address the international demand.
\end{abstract}

Keywords: Internationalization, SMEs, Penta Helix Model 


\section{Introduction}

\section{Background}

For many years, the internationalization of markets, caused by the convergence of the taste across borders, was thought to result in very large multinational enterprises, could use their advantages in scale economies to introduce world-standardized products successfully (Hollensen, 2001). But, with the development of the world company, the international marketplace is much broader and faster changing than before (Craig \& Douglas, 1996). So day after day, large companies drawbacks of inefficiency, bureaucracy and inflexibility have been obviously exposed, while small and medium sized enterprises (SMEs) have more and more chances to enter and share world market (Bradley, 1999).

SMEs have gained several benefits through internationalization, including improved competitiveness acquisition of knowledge. However, researchers have recognized several intrinsic and extrinsic obstacles relating to SMEs internationalization. Most hindrances are linked to managerial, financial, human and informational resource limitations. (Coviello and Munro, 1997)

\section{Research Objective}

The objectives of this research are:

1. To analyze the key important factors in promoting the internationalization preparation of SMEs

2. To analyze the barriers for SME in internationalization preparation of SMEs

\section{Literature Review}

\section{Internationalization}

There are several definition of internationalization, one of definition from the SME context by Ruigrook (2000), states that internationalization can be defined as a movement to international operations. Calof and Beamish (1995) explained the firm's process in adapting to international environments which embraces strategies, structures and resources. Internationalization of a firm is a gradual or sequential process, occurring in many stages. Therefore internationalization of SME is generally defined as the process to increase the involvement in international operations (Welch \& Luostarinen, 1993). Additionally, Lehtinen and Penttinen (1999), states SME internationalization can be referred. The internationalization preparation of SMEs is qualitatively measured based on the readiness on managerial and firm level. The key elements for managerial level are mindset of business owner and entrepreneurial orientation. While the important elements for firm level are business resources, knowledge and networks.

\section{Firm Level of Internationalization}

At the firm level, at least SMEs resources, strategies, knowledge, capabilities, networks and liabilities must be analyzed when the antecedents of SME internationalization are studied 


\section{Macrothink}

Journal of Management Research

ISSN 1941-899X

2017, Vol. 9, No. 4

(Kuivalainen et.al 2012). Understanding the firm level antecedents of internationalization is especially relevant since SMEs differ significantly from each other.

\section{Managerial Level of Internationalization}

Existing international business literature concentrating on understanding SMEs internationalization demonstrates agreement that internationalization is an entrepreneurial activity ( $\mathrm{Lu} \&$ Beamish 2001), and that the owner is a key resource of internationalization (Kannie $\beta$ 2010). Thus, for example Kuivalainen et al (2012) emphasize that managerial level analysis is needed in order to be able to identify possible determinants and antecedents of SME internationalization. Among other things, it is relevant to consider the CEO's mindset, international experience, and entrepreneurial orientation (Kuivalainen et al 2012).

\section{Environmental Level}

Factors of environmental can give impact on the SMEs internalization decisions, either by promoting the firms towards the internationalization, or by creating the entry barriers (Ohman, 2014). As said by Kuivalainen et al (2012), environmental factors consist of factor of industry, technology, competitive, regulatory, market dynamic, distance and many more.

Luostarinen (1997) divided the environmental factors into two categories. The first category is the push factors, which refers to home country factors. Next is pull factors, refers to host country factors that acts as the international pull factors. Bellak and Luostarinen (1994) added that both factors are varied based on the country size and the degree of economic openness to the international market. The smaller and the higher degree of openness more are likely to have

\section{Entry Barriers of Internationalization}

Hollensen (2001) classification of barriers to successful export operations can be identified such as Barriers hindering export initiation, consist of:
a. Insufficient finances
b. Insufficient knowledge
c. Lack of foreign market connections and distribution channels
d. .Lack of export commitment
e. Lack of productive capacity to dedicate to foreign market
f. Management emphasis on developing domestic markets

\section{Financing Problems}

Poor access to capital can stymie the expansion of innovative SMEs, to the detriment of the economy as a whole. From the viewpoint of the banks, creditors' reputation is one of the most important information they collect when considering financial support to a company (Nurzaimah et al., 2016 and Muda et al., 2016). However, establishing reputations are costly and subject to various moral hazard and adverse selection problems. SMEs, thus, have 
imperfect access to capital. And, their imperfect access to capital may force SMEs to limit their size of the physical operations, and the number of people with administrative, operations and marketing expertise, in turn, limit the profits and further development. This lets larger companies earn higher returns than SMEs on similar innovations.

\section{Imperfect Information}

Many barriers to entry are ultimately due to SMEs information disadvantages. Poor information about labor, raw materials, or output market conditions can lead SMEs to make costly mistakes. SMEs may also find it difficult to attract good workers and partner companies because of the higher risks then large companies being viewed.

\section{Entry Barriers Erected by Government}

Perhaps the highest and most economically damaging entry barriers are those erected by governments. Government regulations and restrictions, legal logistics, taxes, and corruption increase the costs of establishing a new company. Baumol (1990), Shleifer and Vishny (1993), Murphy, Shleifer, and Vishny (1993) and Sirojuzilam et al. (2016) argue that artificial barriers to entry encourage innovative people to invest in exploiting the system, rather than in socially useful innovation. In many countries, inspection procedures, safety standards, environmental standards, and other seemingly worthwhile bureaucratic practices may mask barriers to entry that really serve to protect politically entrenched special interests.

\section{Handling entry barriers}

When entering the foreign markets, SME has the barriers of insufficient finances and knowledge, lack of foreign market connections and distribution channels, cultural, competition and language barriers, political risks and trade barriers. Insufficient finances and knowledge barriers are from SMEs own limitations, lack of foreign market connections and distributions channels, cultural, competitions and language barriers are from general environment prevents, payment risks are commercial situation, and health care awareness is from political situation.

\section{Firm Level}

At the firm level, at least SME's resources, strategies, knowledge, capabilities, networks and liabilities must be analyzed when the antecedents of SME internationalization are studied (Kuivalainen et al., 2012). Understanding the firm level antecedents of internationalization is especially relevant since SMEs differ significantly from each other. Moreover, in this chapter, it is necessary to take a look at the three major theoretical approaches, or models of internalization, the eclectic paradigm, the stage models, and the network approach, as they also try to explain internationalization at the firm level.

\section{Research Methodology}

This study uses qualitative research method. Primary Data for qualitative is collected through observation and depth interview on important actors as informants, consist of the four representatives as the adaption of Penta Helix Model, as follow: 
1. Academic or researcher,

2. Business owner

3. Media

4. Association

It was planned to have a depth interview with the representative of government as well. Unfortunately, due to the time and birocracy constraint, we were unable to have a depth interview.

Interview techniques used to collect data from informants is by delivering direct questions and documenting the results. Interviews were also conducted with several times depending on the needs of the research (Muda et al., 2015).

Analysis of this study is by using the Force Field Analysis method to determine the most suited strategies in order to support the internationalization preparation of SME. In addition to that, this research follows the rules of qualitative research by Miles and Huberman (1994) qualitative data analysis, consisting of:

1. Data reduction, to select, simplify, focus, abstracting and transform data.

2. Data display, to take the reduce data and display in organized way to facilitate the conclusions.

\section{Conclusion drawing and verification}

\section{Force Field Analysis}

Force field analysis is a technique for analyzing change in an organization or system, in which the potential for change is measured by the pressures for change (driving forces) versus the pressures opposing change (restraining forces). Thus, change occurs when the driving forces exceed the restraining forces (Smith, 2011; Kurt, 2012). Force Field Analysis (FA) provides a platform for not only understanding and predicting a change situation, but for developing or prescribing a comprehensive change strategy upon which recommendations of the study of a situation can be based.

\section{Results}

Result from depth interview of a group informants, as follow:.

\section{Academic (Lecturer at Management Department in Faculty of Economics and Business in University Sumatera Utara).}

\section{Mindset}

Generally, most owners of SMEs have low international market orientation yet. One of the reasons is because there are still a lot of potentials in domestic market in Indonesia. Indonesia is a huge country with the $4^{\text {th }}$ highest number of population in the world. Hence many of SMEs focus in fulfilling domestic demand. It is only few SMEs are interested in expanding 
the business at international scale. Another reason is because originally the owners do not have the entrepreneurial orientation. They are satisfied with their current condition and do not have any intention to expand their business.

\section{Resources}

Commonly, SMEs' resources are sufficient to expand in international market. As matter of fact, there are a lot of available financing resources for SME and the access is reachable. Meanwhile, there is a lack of competency in human resource. The human resources in SMEs need training to improve the knowledge and skill, so that they are able to produce international standard products and services. Besides the financial and human resources, larger amount of SMES need to upgrade their technology to support the international preparation. In fact, there are many SME owners or managers are not familiar with the development of information technology such as internet.

\section{Competency}

For the early stage, the type of competency which is required to go for international market is business intelligence. Business intelligence is the ability to apply the technology in acquiring information and data analysis to make decision making. Important information to support the preparation international market for instance regulation, permit, quality standard, target market in host country.

\section{Business Sector}

The most developed business sector in Medan definitely is culinary sector compared to other sectors. However the opportunity of culinary sector for international market is lower than other sectors such as handicraft due to its delicateness. SME must be able to master the processing technology to increase the durability of the product, in order satisfy the international standard. On the other hand, handicraft sector has more opportunities in international market culinary due to its uniqueness and high durability, so it will be easy for SME to pack handicraft product with international standard. Unfortunately, the number of craftsmen in Medan is not sufficient. The majority of craftsmen are distributed in the sub districts.

\section{Potential Host Country}

Countries in Africa are very potential as the favorable host country for export due to their flexible trade rules and regulation. Although geographically, ASEAN countries are the most potential host country because of the nearest location and the free trade agreement (ASEAN Economic Community), there are too much similarities between our products and theirs, so our products does not have high demand. Other potential countries are Saudi Arabia, Egypt and other Arabs countries.

\section{Method of Entry}

The suitable method of entry for SME for international market is through business association who act as the intermediaries between SME and target market in host country. 
Currently, the available export import association has not functioned yet. It was just started up by community and collaborated with the Industrial and Trade Office. The other business associations like HIPMI and KADIN has been established considerably long but not specifically deal with export import.

\section{Role of other party}

The role of all related stakeholders is important to prepare the SME in international market. Scholar can involve in providing training, educating and information sharing for SME. Government is responsible to facilitate the regulation, permit, the representative of SME in host country and many more. Furthermore, media can promote the SMEs products to be well-known worldwide. The rules, regulation and programs provided by government should be able to support the competitive products in Medan. Medan can duplicate Bandung with its Bandung Creative City program.

\section{Challenges}

The first challenge is from the mindset of the SMEs owner, most owners do not have international orientation. Other important challenges are lack of information possessed by the manager of SMEs, lack of socialization activity conducted by government, lack of willingness from owner to search related information for internationalization preparation and Information Technology illiterate.

\section{Strategy}

At this stage, it is better for the SME to utilize the usage of Information Technology, as a cost saving and friendly user technology such as Media Social application. The function of this application is for the purpose of products and services promotion. For instance by using the fan page from Facebook ( $f b$ ) which is cheaper than common advertisement with wide network coverage, therefore the possibility to attract potential consumers will increase. Besides Facebook, Instagram marketing is one of effective tools to promote, build the brand awareness through the increasing number of followers.

\section{Business Association (Prof. Dr. Ritha F Dalimunthe, SE)}

\section{Mindset}

Most of SME owners are not ready to join in international market because lack of entrepreneurial orientation. Therefore it is needed to conduct sustainable assistance activities from the information searching, capacity building and many more.

\section{Resources}

Resources owned by SMEs are ready to start the process of internationalization. Although there are still some factors that can be optimize such as IT (Information Technology) and technological equipment. Moreover it is essential to improve the skill of the human resources of the SME, in order to support the internationalization process.

\section{Business Sector}


In fact, the majority of business sectors in North Sumatera have a great potential to initiate the international market, especially the handicraft sectors such as Ulos (Traditional woven handicraft). This sector is one of the highest potential internationalization of SME. The basic reason is because of the uniqueness of the product and the identity of the local content.

\section{Country of destination}

Saudi Arabia, the United Arab Emirates and Egypt are the most prospect countries destination for handicraft sectors. The differences of culture, the geographical location and custom are the main reason why they welcome the handicraft product. However, those countries have flexible rules and regulation in terms of internationalization process.

\section{Method}

In order to start the internationalization process, the business owners of SMEs are able to join in specific training conducted by PPEI as the training center for export. This training will be able to assist all SMEs to find all related information about export import, rules and regulation, strategies and preparing all the paperwork. It is hoped that by joining the training, the barriers can be decreased and afterward, SMEs will be willing to initiate the internationalization process through PPEI.

\section{The role of other parties}

The role that is expected from other parties is to do the mentoring role as well as being an intermediary between the SMEs to the intended market. In general, SMEs basically have the readiness in terms of resources but do not have a network to distribute its products to the international market. Unfortunately the big potential market cannot be absorbed by the SMEs due to those issues. Below is the expected role by the other parties.

1. Central bank of Indonesia has the SME Center to encourage the development of SMEs in the process of internationalization. SME Center is to facilitate SMEs in terms of providing information for business initiation, products packaging, branding, licenses, legal permissions, food and drug licenses, and halal certificate, promotions, rules and regulation for export and import.

2. Mentoring conducted by the PPEI, which was established by the Directorate General for National Export Development, with fund aid from JICA. The mentoring aims to facilitate SMEs in entering the international market.

3. Socialization is done by the Ministry of industry as a government agency that plays a direct role to regulate the issue of export import.

\section{Challenge}

The common challenges faced by SMEs are the proactive characteristic of SMEs. Most of SMEs owners are not proactive to search all related information about internationalization. For example: legal paper work processing, market research, product quality requirement and the conditions of destination country. 


\section{Strategy}

Cross-sectorial integration is an ultimate strategy that must be applied for SMEs in the process of internationalization.

\section{Media (Mr. Karnadi)}

\section{Mindset}

Young generation of SMEs owners already have international orientation for business expansion, such as exporting to Malaysia and Thailand. Most of them are in fashion sector, which have fast fashion updates. On contrary, older generation of SMEs owners have different mindset. They would rather focus in domestic market than to have international business expansion, by opening new branches. In fact, it is hardly ever for them to share their business success to other people. It is because the business success will be only shared among the family member.

\section{Resource}

\section{a. Human Resources}

In general, SMEs owners in Medan have sufficient number of human resources, even though it has the lower quality of skill and experiences for international market. Therefore the improvement of an international exposure would be beneficial for them.

\section{b. Technology Resources}

In reality, technology is not the major handicap for SMEs owners in the process of internationalization. Nowadays, there is a lot of user friendly business software to boost the performance of business, with reasonable price available. Additionally, various applications on internet also efficient and effective mean for business performance.

\section{c. Financial Resources}

There are a lot of financial sources to fund SMEs for international business expansion. The fundamental issue is not the sources of fund but more likely to the inability in accessing the fund, fulfilling the funding requirements and acquiring bank trust.

\section{Business sector}

Of all the business sectors, culinary and handicraft sectors have the highest potential for international market. The current barrier is the lack of brand awareness conducted by the SMEs owners. In fact, some of them do not have brand and sell their products under other's brand. It means that their products are labeled by other brands.

\section{Country of destination}

Southern African countries have a huge market potential for SMEs to enter the international market, as markets in southern Africa have a great fondness towards the genuine local products Indonesia. 


\section{Method}

One of methods to internationalize the product can be conducted through distributors, which act as a wholesaler to be exported. As an example, Cassava Chips products have been exported to South Korea. The exporter was successfully done due to the collaboration with local government, with acted as the intermediaries between the business owner and country of destination.

\section{The role of other parties}

The role of government in supporting the "integrated services of permit" (one stop services) is deeply essential for the owner or manager of SMEs to face the internationalization. The other important role for government is by including the SMEs for national or international trade exhibition.

\section{Challenge}

Actually the biggest challenge is from the owner of SMEs themself due to the lack of entrepreneurial mindset. Most of SMEs owners do not have the ambition expand their business, lack of future orientation and insufficient management for their business.

\section{Strategy}

Each of SMEs has different type of applicable strategies for their business. However, the most basic strategy should possess the uniqueness and the ability to keep up with the customer preference.

\section{Business Owner of SME}

\section{Mindset}

1. Why do you want to have an international expansion?

The reason of course because to expand the market while learning new think from the market regarding the attitude, behavior, business system and specific thinks about exported such as letter of credit, guarantor of exporting and other related information.

2. Is the internationalization beneficial for your business?

Yes, It is very beneficial, it is a good way to expand my market coverage as well have a change for business opportunities.

3. Do you have enough information on how you can start the internationalization?

Yes, I do. I have a lot of information from the travel association, HIPMI and KADIN. The basic requirement is to have passport, visa and the legal document of organization.

\section{Proactive}

1. Do you look for information about the internationalization? 
Yes of course. The general information I accessed through internet, and for detail I accessed from the travel association through social media like WhatsApp. In addition, I regularly join the mentoring from the experienced business owners in HIPMI.

2. How do you anticipate the global challenge?

By giving competitive price, regular promotions in social media, massage broadcasting, best services and maintaining the emotional bonding by having regular communication to all customers.

\section{Opportunity Focus}

1. Do you try to find out any business opportunities through the internationalization?

Yes, I do. I always look for business opportunities by reading latest news, so it would give enough information to analyze the market demand for international market.

\section{Risk Taking}

1. Have you done any risk analysis to enter that international market?

Yes, I have. I think the biggest risk to enter that international market is to find trusted person to be my partner.

2. After you have realized the risk, do you dare to take the risk (international market)?

Definitely I would take the risk, because I believe the profit will be higher than the risk. It has encouraged me to develop the business and continuously scan for the new market.

\section{Inovation Oriented}

1. What kind of innovation that has you plan to enter the international market?

By creating an innovative pricing strategy, providing, trusting tourism package and android as well as IOS base travel application.

2. What kind of innovation that have done?

Innovative price, tourism package and have provided services for those who want to start travel business.

\section{Consumer Intencity}

1. Have you ever had any relationship with customer in international market?

Yes, I have. By learning international language and using simple language to communicate with the customers.

\section{Company Level (Firm Level)}

1. Does your business have the financial resources to enter the international market? If yes, where it is come from or what are your funding sources? 


\section{Macrothink}

Journal of Management Research

ISSN 1941-899X

2017, Vol. 9, No. 4

Yes, I have sufficient financial resource to enter the international market. The funding source is from business profit.

2. How about the tangible resources for international market such as equipment, raw materials and infrastructure?

My business has all the important tangible resources. The most important equipment to maintaining the international customer at the moment is the digital equipment.

3. Are your human resources ready to international market?

Yes, they are ready for international market. Even though, they need to increase their English ability. In my opinion beside English, another language for international market is mandarin. Hence, I have intensive mandarin class currently.

4. Is there any collaboration with other parties for international market (agent, association, friends, relatives in oversea)?

Yes, I have a contact business in other country. This was introduction by my friend. Our good business relationship has been lasted long until now.

5. Have you ever had any experience for international market previously?

Yes, I have started since end of 2015.

\section{Force Field Analysis}

To analyze the important key factors and obstacles in promoting the internationalization of SMEs preparation then used Force field Analysis. The force field analysis is useful "for diagnosing a situation by looking at both the driving and restraining forces that influence change in an organization (Witkin \& Altschuld, 1995, p.94). 


\section{Macrothink}

Table 1. Driving and Restraining Forces in Internationalization Preparation

\begin{tabular}{|c|c|c|c|c|c|c|c|c|c|}
\hline No & Driving Forces & $\mathbf{N U}$ & BF & ND & NBD & NK & NBK & TNB & KKK \\
\hline & Strength: & & & & & & & & \\
\hline 1 & The uniqueness of product & 5 & 0.55 & 5 & 2.75 & 5 & 2.75 & 5.50 & $\checkmark$ \\
\hline \multirow[t]{3}{*}{2} & $\begin{array}{l}\text { Able to apply the IT for } \\
\text { promotion }\end{array}$ & 4 & 0.45 & 5 & 2.25 & 4 & 1.80 & 4.05 & \\
\hline & Total Strength & 9 & & & & & & 9.55 & \\
\hline & Opportunities: & & & & & & & & \\
\hline 3 & $\begin{array}{l}\text { The availability of SME } \\
\text { center }\end{array}$ & 4 & 0.22 & 5 & 1.10 & 5 & 1.10 & 2.20 & \\
\hline 4 & $\begin{array}{l}\text { The availability of business } \\
\text { association }\end{array}$ & 5 & 0.26 & 4 & 1.04 & 5 & 1.30 & 2.34 & \\
\hline 5 & High international demand & 5 & 0.26 & 5 & 1.30 & 5 & 1.30 & 2.60 & $\checkmark$ \\
\hline \multirow[t]{4}{*}{6} & $\begin{array}{l}\text { Sufficient financial support } \\
\text { from government }\end{array}$ & 5 & 0.26 & 4 & 1.04 & 5 & 1.30 & 2.60 & \\
\hline & Total opportunities & 19 & & & & & & 9.74 & \\
\hline & Restraining Forces & & & & & & & 19.29 & \\
\hline & Weakness: & & & & & & & & \\
\hline 1 & Insufficient business network & 5 & 0.29 & 5 & 1.45 & 5 & 1.45 & 2.90 & $\checkmark$ \\
\hline 2 & $\begin{array}{l}\text { Lack of knowledge in term of } \\
\text { rules, regulation, permit for } \\
\text { international market }\end{array}$ & 5 & 0.29 & 5 & 1.45 & 5 & 1.45 & 2.90 & \\
\hline 3 & $\begin{array}{l}\text { Lack of entrepreneurial } \\
\text { orientation }\end{array}$ & 4 & 0.23 & 4 & 0.92 & 4 & 0.92 & 1.84 & \\
\hline \multirow[t]{3}{*}{4} & $\begin{array}{l}\text { Lack of competencies of } \\
\text { human resource }\end{array}$ & 3 & 0.17 & 5 & 0.85 & 3 & 0.51 & 1.36 & \\
\hline & Total weakness & 17 & & & & & & 9 & \\
\hline & Threats: & & & & & & & & \\
\hline 5 & $\begin{array}{l}\text { High competition from other } \\
\text { countries }\end{array}$ & 5 & 0.62 & 5 & 3.10 & 5 & 3.10 & 6.20 & $\checkmark$ \\
\hline \multirow[t]{3}{*}{6} & $\begin{array}{l}\text { Lack of support from } \\
\text { government in term of } \\
\text { program }\end{array}$ & 3 & 0.38 & 4 & 1.52 & 3 & 1.14 & 2.66 & \\
\hline & Total weakness & & & & & & & 8.86 & \\
\hline & & & & & & & & 17.86 & \\
\hline
\end{tabular}

According to table 1, it can be seen the driving forces for internationalization preparation for SME embraces of strengths as the internal factors and opportunities as the external forces which supports SME to enter the international market. score of driving forces is 19.29 and the score of restraining forces is 17.86 . 


\section{Macrothink}

Journal of Management Research

ISSN 1941-899X

2017, Vol. 9, No. 4

Table 2. Identification of Driving and Restraining Forces for Internationalization Preparation

\begin{tabular}{|c|c|c|c|c|c|}
\hline No & Driving forces & TNB & No & Restraining Forces & TNB \\
\hline & Strength & & & Weakness & \\
\hline 1 & $\begin{array}{l}\text { The uniqueness of } \\
\text { product }\end{array}$ & 5.50 & 1 & Insufficient business network & 2.90 \\
\hline \multirow[t]{5}{*}{2} & $\begin{array}{l}\text { Able to apply the IT for } \\
\text { promotion (e.g. social } \\
\text { media) }\end{array}$ & 4.05 & 2 & $\begin{array}{l}\text { Lack of knowledge in terms of rules, } \\
\text { regulation, permit of international } \\
\text { market }\end{array}$ & 2.90 \\
\hline & & & 3 & Lack of entrepreneur orientation & 1.84 \\
\hline & & & 4 & $\begin{array}{l}\text { Lack of competencies of human } \\
\text { resource }\end{array}$ & 1.36 \\
\hline & Total strengths & 9.55 & & Total weaknesses & 9 \\
\hline & Opportunities & & & Threats & \\
\hline 3 & $\begin{array}{l}\text { The availability of SME } \\
\text { center }\end{array}$ & 2.20 & 5 & $\begin{array}{l}\text { High competition from other } \\
\text { countries }\end{array}$ & 6.20 \\
\hline 4 & $\begin{array}{l}\text { The availability of } \\
\text { business association }\end{array}$ & 2.34 & 6 & $\begin{array}{l}\text { Lack of support from government in } \\
\text { term of program }\end{array}$ & 2.66 \\
\hline 5 & $\begin{array}{l}\text { High international } \\
\text { demand }\end{array}$ & 2.60 & & & \\
\hline \multirow[t]{3}{*}{6} & $\begin{array}{l}\text { Sufficient financial } \\
\text { support from government } \\
\text { (e.g. loan, micro credit) }\end{array}$ & 2.60 & & & \\
\hline & Total opportunities & 9.74 & & Total threats & 8.86 \\
\hline & Total driving forces & 19.29 & & Total restraining forces & 17.86 \\
\hline
\end{tabular}

According to table 2, the value of driving factor is 19.29 and the total restraining factors is 17.86. It means the value of total driving factors is higher than the restraining factors. It indicates the prospect of internationalization is in the positive situation for SME in Medan. Next, the key factors in the internationalization preparation for SME in Medan can be measured by selecting the key success factors based on the highest weight in driving factors and restraining factor. 
Driving Forces

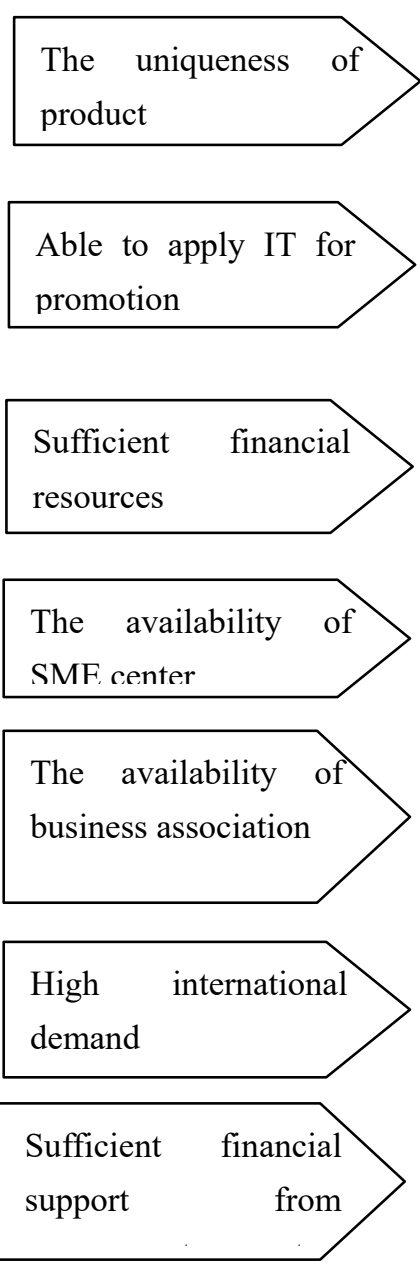

\section{Restraining Forces}

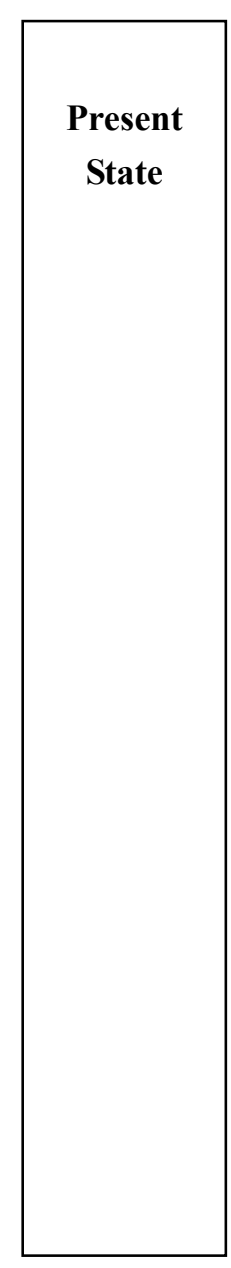

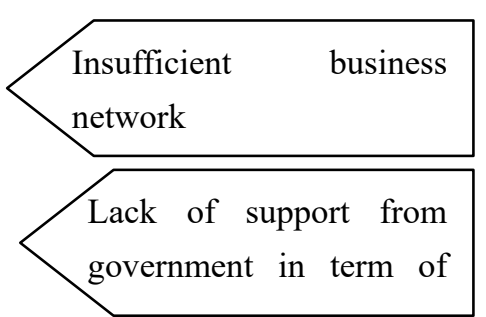
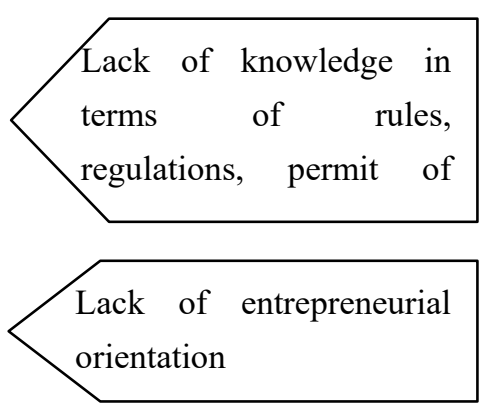

Lack of competencies of

human resources

Lack of international orientation in business

High competition from other countries

Figure I. Driving and Restraining Forces (Processed Data, 2016)

\section{Discussion}

In order to develop comprehensive recommendation in preparing international market, penta helix model which involve five informants as the important actors is use in this research.

\section{Recommendations for Business Owner (SME)}

Based on the force field analysis, it was found the key success for business owner is by utilizing the strength to encounter the threat, and exploiting opportunities to minimize the weaknesses owned by SME. Below is the illustration of the recommendation:

Table 3. Key Success Factors For Business Owner (SME)

\begin{tabular}{|l|l|}
\hline Driving Factors & Restraining Factors \\
\hline Strength & Weakness \\
\hline The Uniqueness Of Product & Insufficient business network \\
\hline Opportunity & Threat \\
\hline High International Demand & High Competition From Other Countries \\
\hline
\end{tabular}


Source: Processed Data (2016)

Based on the table 3, the most possible recommendations which will be appropriate for the internationalization preparation of SMEs in Medan are:

1. Focusing in the uniqueness of product through optimizing the SME's innovation capacity in order to win over the market competition from other countries. Company should commit in allocating all the essential resources to support the innovation capacity to create unique design, quality and taste. For instance, SME conducts a deeper exploration on the local content to be applied in the products. This approach will differentiate the SME products from other countries.

2. Establishing a wider and stronger business network in order to full fill the international demand. Therefore the higher degree involvement of business association is very important to assist and expand the networking.

\section{Comprehensive Recommendation in Promoting the Internationalization Preparation of SME's}

Based on the results from depth interviews, the recommendation in promoting the internationalization preparation is given based on the penta helix model. There are five informants who act as important actors in promoting the internationalization as follow:

1. Academic or researcher,

2. Government sector (Industrial and Trade)

3. Business owner

4. Media

5. Association

Each of them have different roles, however it is expected to be a synergy in order to encourage the internationalization process for SMEs. 


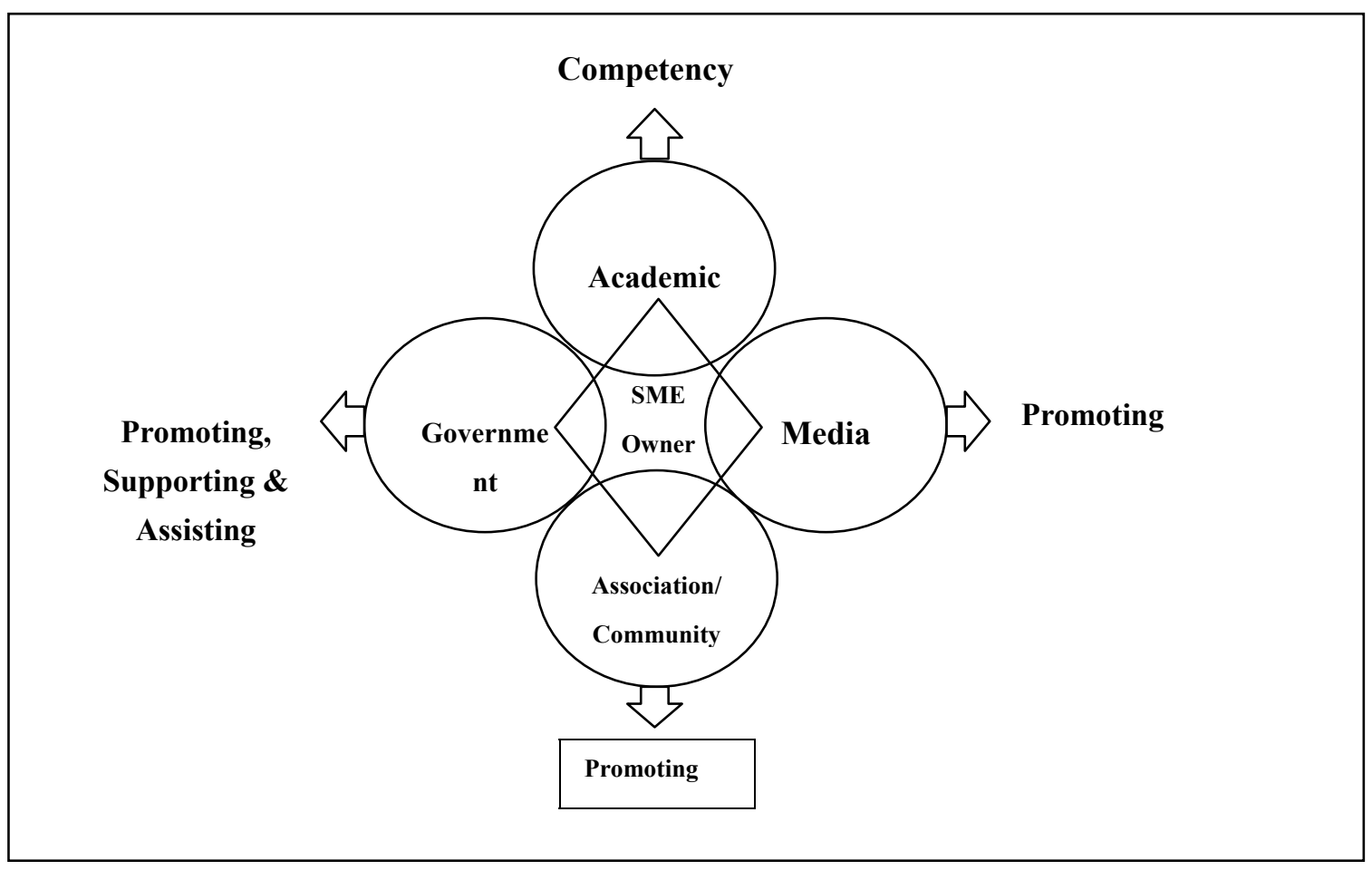

Figure 2. Comprehensive recommendation to support the Internationalization preparation of SME

The expected roles for each informant are as follows:

1. Academic, act as an actor to improve the competency SME owner / manager through training, educating and information sharing

2. Media, take part in promoting the SME's products or services worldwide through publication

3. Association/community has many roles in the international preparation of SME. The first role is to promote SME's product or services. The second is to act or the intermediaries to link the SME's is to assist SMEs in the whole process from the beginning

4. The Government has the highest responsibility in international preparation of SME. It involves in any type of activity, such as, promoting, assisting, financial allocation, permit, program, law and many more

5. SME Owner, It is essential to cultivate a new paradigm so that they will have entrepreneurial orientation, proactive in searching related information regarding the internationalization, expanding the network coverage, the readiness of organizational resources.

This recommendation is supported by Leonidou (2004) and Hollensen (2001), which is in the early stages of internationalization, SME experiences scarcity of resources in terms of information and knowledge about international market, which is one of the barriers for internationalization. The scarcity of market knowledge will raise a misperception about the 
real condition of international market such as market risk, market demand and many critical aspects of international market. It will result to a reluctant feeling for business owner to start the internationalization. Therefore, it is crucial for all the related actors to involve in solving the scarceness of knowledge by business owner.

In order to minimize the weakness of business owner in the process of internationalization, namely insufficient business network, association/community and government can take part as the intermediary to link the SMEs and potential buyer in the international market. Government also can take to encourage in terms of promoting and assisting to find a trusted business network in international market. This recommendation is supported by Chetty and Blankenburg-Holm (2000); Agndal and Chetty (2007), stated the business network and good relationship are vital factor to resolve the challenge. Business network would not only beneficial for business owner in terms of profit but also knowledge, specific skills and resources for SMEs.

It is plausible that a number of limitations may have influence the result obtained, due to our inability to have a depth interview with the representative of government, who directly in charge in this subject. The findings of government roles were merely from the interview with other informants (academic or researcher, media, business owner association) not with the government directly. Inevitably the research would be better if the future research can have a direct interview with the government.

\section{Conclusion}

1. The key important factors in promoting the internationalization preparation of SMEs are the uniqueness and the high international demand of product.

2. The barriers for SMEs in internationalization preparation are insufficient business network and high competition from other countries.

3. Recommendations for SME business owner:

a. Optimizing innovations that incorporate local elements to produce a unique product that can compete with other countries.

b. Establishing a wider and stronger business network in order to full fill the international demand.

4. Comprehensive recommendations in promoting the internationalization preparation is by involving the role of important actors from different backgrounds such as (Academic or researcher, Government sector (Industrial and Trade), Business owner, Media and association, which is expected to be a synergy that can encourage the internationalization process for SMEs.

\section{References}

Agndal, H., \& Chetty, S. (2007). The Impact of Relationships on changes in Internationalization Strategies of SMEs. European Journal of Marketing, 41(11/12). 1449-1474. https://doi.org/10.1108/03090560710821251 
Baumol, W. J (1990). Entrepreneurship: Productive, Unproductive and Destructive, Journal of Political Economy, 98, 893-921. https://doi.org/10.1086/261712

Bradley, F. (1999). International Marketing Startegy. Third Edition, Prentice Hall Europe.

Calof, J., \& Beamish, P., (1995). Adapting to foreign markets: explaining internationalisation, International Business Review, 4(2), 115-31. https://doi.org/10.1016/0969-5931(95)00001-G

Chetty, S., \& Blankenburg-Holm. D, (2000). Internationalisation of small to medium sized. Medium-Sized manufacturing firms: A network approach. International Business Review, 9(1), 77-93. https://doi.org/10.1016/S0969-5931(99)00030-X

Coviello, N., \& Munro, H. (1997). Network relationships and the internationalisation process of small firms. International Business Review, 6(4), 361-386. https://doi.org/10.1016/S0969-5931(97)00010-3

Craig C.S., \& Susan P. Douglas. (1999). Conducting International Marketing Research in the 21 st Century. International Marketing Research, Environmental Change.

Hollensen, S (2001). Global marketing: A Market-Responsive Approach, Second edition, Prentice Hall Europe.

Kaufmann D., \& Michael Kannieb. (2010). Key Factors for Successful Internationalization of SME's in Transition Economies in South Eastern Europe in the Light of Global Recession. Conference Proceedings: International Conference of The Faculty.

Kuivalainen O, Sanna Sundquist, \& Sami Saaren keto. (2012). Internationalization Patterns of Small and Medium-Sized Entreprises. International Marketing Review, 29(5), 448-465. https://doi.org/10.1108/02651331211260331

Kuivalainen, O., Puumalainen, K., Sintonen, S., \& Kylaheiko,K. (2010). Organisational capabilities and internationalization of the small and medium-sized information and communications technology firms. Journal of international Entrepreneurship, 8(2), 135-155. https://doi.org/10.1007/s10843-010-0057-7

Lehtinen, U. and Penttinen, H. (1999). Definition of the internationalization of the firm, in Lehtinen, U. and Seristoe, H. (Eds), Perspectives on Internationalization, Helsinki School of Economics and Business Administration, Helsinki, pp. 3-19.

Leonidou. L. C (2004). An Analysis of the Barriers Hindering Small Business Export Development, Journal of Small Business Management, 42(2), 279-302.

Lu, J.W., \& Beamish, P.W. (2001). The Internationalization and Performance of SMEs. Strategic Management Journal, 2(1), 565-586. https://doi.org/10.1002/smj.184

Miles, M.B., \& Huberman, A.M. (1994). Qualitative Data Analysis, Thousand Oaks, CA: Sage

Muda, I., \& Abykusno Dharsuky. (2015). Impact Of Region Financial Information System (SIKD) Quality, Role Ambiguity And Training on Precision of Financial Statement of Local 
Government Presentation In North Sumatra. International Journal of Applied Business and Economic Research, 13(6), 4283-4304

Muda, I, Marlon Sihombing, Erni Jumilawati, \& Abikusno Dharsuky. (2016). Critical Success Factors Downstream Palm Oil Based Small And Medium Enterprises (SME) In Indonesia. International Journal of Economic Research, 13(8), 3531-3538.

Murphy K.M., Shleifer. A., \& Vishny. (1993). Why is Rent-Seeking So Costly to Growth?, American Economic Review Paper and Proceedings, 83(2), 409-414.

Nurzaimah, Rasdianto, \& Muda, I. (2016). The skills and understanding of rural enterprise management of the preparation of financial statements using Financial Accounting Standards (IFRs) financial statement on the Entities without Public Accountability (ETAP) framework on the implementation of village administration law. International Journal of Applied Business and Economic Research, 14(11), 7417-7429.

Ohman. E. (2014). Antecedants of SME Internationalization: Multiple Case Study of Finnish $S M E$ 's Expansion into Estonia, Dept of Management Studies Alto University of School of Business, Finland.

Ruigrok, W. (2000). Globalisation and small and medium sized enterprises: an unlikely marriage that works", keynote speech, Conference proceedings, Concerted Action Seminar on SME Support Services in The Face of Globalisation, Danish Agency for Trade and Industry, Copenhagen, pp. 29-37.

Shleifer A., \& Vishny R.S (1993), Corruption, The Quarterly Journal of Economics, 108(3), 599-617. https://doi.org/10.2307/2118402

Sirojuzilam, Hakim, S., \& Muda, I. (2016). Identification of factors of failure of Barisan Mountains Agropolitan area development in North Sumatera- Indonesia. International Journal of Economic Research, 13(5), 2163-2175.

Welch, L.S., \& R.K. Luostarinen. (1993). Inward-Outward Connections in Internationalization. Journal of International Marketing, 1(1), 44-56. 